\title{
The Effect of Experimental Prescribed Fire on White Pine Regeneration
}

\author{
Michael J. Drews* and Todd S. Fredericksen
}

\author{
Georgia Southern University, Ferrum College, Ferrum VA, 24088, Ferrum, VA 24088, USA
}

\begin{abstract}
We examined the effects of prescribed fire on white pine (Pinus strobus) advance regeneration in small experimental plots in mixed hardwood-pine forests in southwestern Virginia during the fall and spring. Fires killed all newly germinated seedlings in both spring and fall. Saplings (ranging from $0.7-3.4 \mathrm{~m}$ in height) all suffered some degree of crown scorch, but sapling survival was higher on plots burned in the fall (54\%) compared to those burned in the spring $(20 \%)$. After one growing season following the fires, seedling density had recovered to a level similar to that of control plots for fall burns, but was still significantly lower than control plots for spring burns. After one growing season, the amount of crown mortality for saplings was reduced with increasing height and root collar diameter. Height growth of saplings after one growing season following fires was not different between burned and control plots. Fall burns may be less detrimental to white pine regeneration because of reduced mortality to saplings and by providing microsite conditions during the period of seed rain that are conducive to recover seedling regeneration.
\end{abstract}

Keywords: Crown scorch, fire, Pinus strobus, prescribed burning, regeneration, white pine.

\section{INTRODUCTION}

Fire has played an important role in shaping forest composition in the southern Appalachian Mountains [1, 2]. Periodic low intensity fires were thought to have maintained pine and oak forests, and stand-replacing fires following logging also contributed to the establishment of firedependent species [3]. Fire suppression over the past few decades has led to shifts in species composition with increasing dominance of fire-intolerant species, such as Red Maple (Acer rubrum) and American Beech (Fagus grandifolia) $[4,5]$. Many of these species are also shadetolerant and regenerate well in forest understories. They also tend to be less economically and ecologically valuable compared to oaks $[6,7]$.

One species with a relatively high timber value that is regenerating well in the southern Appalachians is Eastern White Pine (Pinus strobus). It is a mid-successional species that is moderately-tolerant of shade. Because of this, white pine often occurs in mixed stands with hardwoods and is able to successfully regenerate in the forest understory $[8,9]$. While seedling regeneration of this species may occur in diverse conditions in the understory, gaps promote the recruitment of seedling into the sapling and pole size classes. Gaps created in the forest canopy from downed trees allow for cohorts of white pine to regenerate in patches $[10,11]$. Fredericksen and Endara-Agramont 2013 [12] found that white pine recruitment into the sapling and pole class is dependent on at least $20 \%$ of full sunlight.

The role of fire in controlling and determining the relative importance of white pine in mixed pine-hardwood

*Address correspondence to this author at the Georgia Southern University, Statesboro, Georgia 30460, USA; Tel: (571) 296-6954;

E-mails:md04378@georgiasouthern.edu,mdrews@ferrum.edu forests is unclear. White pine has some traits that could be considered to be fire-adaptive. Mature white pine trees have thick bark, which allows the interior cambium of the tree to be insulated from fire for a period of ten-fifteen minutes [10, 13]. High-intensity, stand replacing fires prepare seedbeds favorable for white pine regeneration, eliminating competition and increasing the availability of light for subsequent growth of seedlings $[14,15]$. Unlike more intense stand-replacing fires, low-moderate intensity fires can also increase the regeneration of mid-successional species such as white pine by eliminating invasion of early and late-succession species while also preparing seedbeds favorable to white pine seedlings [16]. Throughout the last century, the suppression of fire has led to the decline of white pine (Pinus strobus) in the Great Lakes and Eastern Canada [17, 18], but fire suppression in the southern Appalachians seems to have favored the regeneration of white pine $[12,19]$. If advance white pine regeneration is present, however, seedlings and saplings may be vulnerable to fire. White pine seedlings and saplings do not resprout after being top-killed by fire and their thin bark makes it likely that fire would kill the cambium [20]. Blankenship and Arthur [19] reported that a single prescribed fire removed all white pine $<2.0 \mathrm{~cm}$ dbh from oak-pine forests in eastern

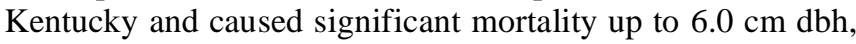
but they also noted abundant post-burn colonization of white pine. Low intensity prescribed burning eliminates competing vegetation and removes the duff layer, creating favorable conditions for white pine regeneration $[18,21]$.

While the effect of more intense wildfires on white pine regeneration has been studied, less information is available about the ecological impacts and significance of lowintensity fires. Low-intensity fires can affect many aspects of a forest ecosystem including seedling density, sprouting, vegetative cover, richness, litter depth, proportion of exotic species, and soil properties [16]. It is uncertain how low- 
intensity prescribed fire may affect white pine regeneration after decades of fire suppression.

The objectives of this study are to determine the mortality rate of white pine saplings in temperate deciduous forests after being subjected to low-intensity fires and to determine if recruitment and growth of new regeneration offsets mortality from fire. We hypothesized that white pines in the sapling class may suffer some mortality due to lowintensity fires with taller saplings with a larger stem diameter likely to suffer less mortality. Although seedlings may have higher mortality, new seedling regeneration will lead to greater overall white pine seedling and sapling density following low-intensity fires. In addition, trees that survive but are injured by the fire (crown scorch, cambial damage) will have reduced growth. We also hypothesized that the timing of fire (late fall compared to early spring) may affect white pine mortality, growth and regeneration resulting from the fire with spring fires likely to cause more damage because trees are emerging from dormancy.

\section{METHODS}

The study was conducted in the forests on the campus of Ferrum College, in Franklin County, Virginia, USA (N

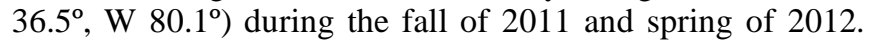
Conditions typical of the study site include gentle sloping hills with a temperate climate. Forest stands used for this study were 90-100-year-old mixed white pine-hardwood forests, including red maple (Acer rubrum), tuliptree (Liriodendron tulipifera), oaks (Quercus spp.), and sourwood (Oxydendrum arboreum). Stands were subjected to light high-grade logging during the 1970s and 1980s. The gaps from this logging resulted in patches of white pine regeneration within the forest [12]. Elevation ranges from 335 to $450 \mathrm{~m}$ and slopes from 0 to $30 \%$. Soils are predominantly well-drained Clifford sandy loams and eroded clay loams of the Woolwine-Fairview-Westfield complex (USDA National Resources Conservation Service, Web SoilSurvey). Mean minimum and maximum temperatures are -3 and $8^{\circ} \mathrm{C}$ for winter and 15 and $28^{\circ} \mathrm{C}$ for summer months (Rocky Mount, VA Weather Station, Southeast Regional Climate Center). Mean annual precipitation is 113 $\mathrm{cm}$.

In the fall of 2011, ten paired plots (burned and control plots) were selected in the forest for a fall burning treatment. Each plot was located around a patch of white pine saplings ranging from $0.7-3.4 \mathrm{~m}$ in height $($ mean $=1.7)$ and between 0.8 and $4.7 \mathrm{~cm}$ root collar diameter (mean $=2.7$ ). Plot pairs were located on a range of aspects and slope positions, but none were on slopes > 5\%. Similarly, another ten paired plots were located for treatment in the spring of 2012. Ultimately, only eight of these plots were burned because of weather conditions that were not conducive to burning.

Each plot was $5 \mathrm{~m} \times 5 \mathrm{~m}$ in size and pairs of plots was located within $3 \mathrm{~m}$ of one another. One of each plot pair was randomly assigned to be burned, with the other as a control. Within each of the $5 \mathrm{~m} \times 5 \mathrm{~m}$ plots, five white pine saplings were tagged and measured for both height and stem diameter at the base of the sapling at the root collar (measured in two perpendicular directions and averaged). A count on the number of seedlings occurring in each plot was also recorded. Sites selected contained white pine regeneration ranging from the seedling to the sapling class. The distance from the plots to the closest potential white pine seed source was recorded.

Fall burns were carried out in late October and early November, while spring burns were carried out in late March. All burns were set after 4 p.m. in compliance with local fire laws because both fall and spring burn periods coincided with periods of elevated wildfire danger. Burn conditions varied by time of burn for the plots, but daytime prescriptions followed for the burn included temperature ranges from $10-15{ }^{\circ} \mathrm{C}$, relative humidity between $30-55 \%$, and wind speeds less than $8 \mathrm{~km} /$ hour. A fire line dug to the mineral soil was constructed around each of the ten plots using a fire rake. An equal mixture of kerosene and diesel fuel was used in a drip torch to start the fire. All sites were allowed to burn completely. The fires that were lit were considered low-intensity fires, burning mostly the leaf litter down to the duff layer.

In May following the spring burns, the percentage of the crown affected by the fire was recorded for all white pine saplings within the plots. Crown mortality was evaluated as the percentage of the crown with dead foliage using the following categories: $1=0 \%, 2=1-25 \%, 3=26-50 \%, 4=$ $51-75 \%, 5=76-99 \%, 6=100 \%$.

In October, 2012, the number of seedlings (new germinants without woody stem and branching) and saplings (all other trees $<3.5 \mathrm{~m}$ tall) in all plots was counted to assess impacts on regeneration after one growing season. In April, 2013, all tagged saplings were assessed for mortality and, for live trees, the internode length of the stem representing growth during 2012 was measured with a ruler.

For all plots, data were averaged or summed for each plot and analysis were carried out at the plot level $(\mathrm{n}=10$ for fall plots and $n=8$ for spring plots). The comparison of season of burn for crown scorch and sapling survival on burned plots was carried out using a t-test following a square root transformation of the percentage data. Tests for differences in seedling and sapling density on paired burned and control plots was carried out using a Wilcoxon rank sum test because of assumptions were not met for a parametric test. A paired t-test was used for comparing sapling growth on burn and control plots for the fall burn plots only. There were not enough surviving saplings on spring burn plots for a robust test.

\section{RESULTS}

Crown mortality on white pine saplings assessed shortly after the burn was more severe in the spring burn than in the fall burn (Fig. 1). All saplings in burn plots had some signs of crown mortality, typically on the lower branches due to crown scorch. For fall burns, the degree of crown mortality was bimodal with some saplings showing relatively little crown mortality and others a high percentage of crown scorch. Crown mortality on spring plots tended to be severe for most saplings (Fig. 1). Sapling survival was significantly $(p=0.02)$ higher on plots burned in the fall $(54 \%)$ than for those in plots burned in the spring (20\%). 


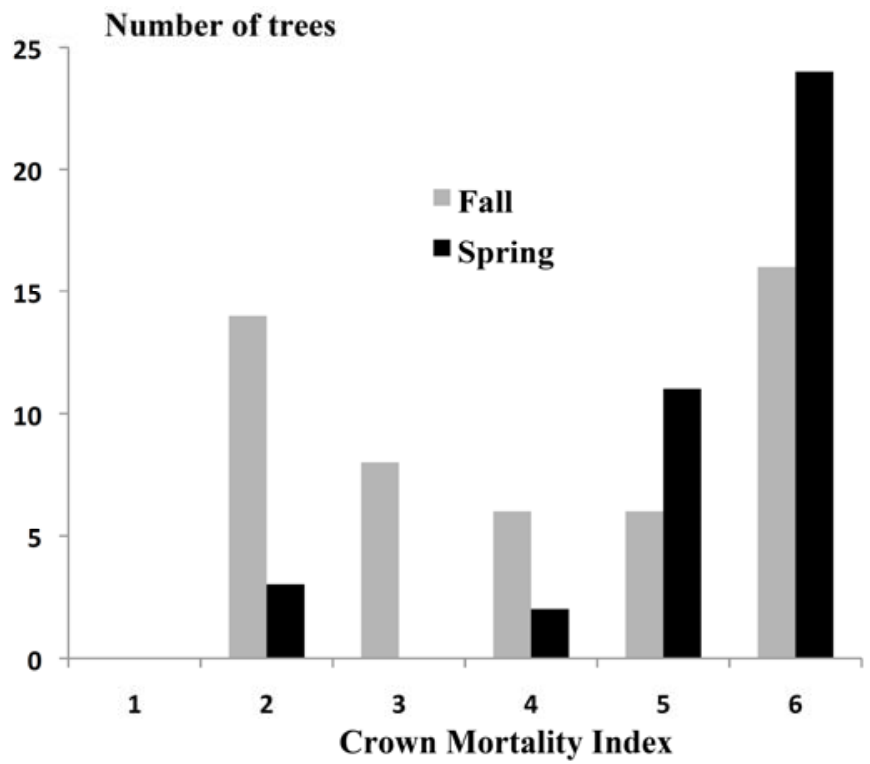

Fig. (1). Crown mortality index of white pine saplings following burning in spring or fall. Index key: $1=0 \%$ of crown affected, $2=$ $1-25 \%, 3=26-50 \%, 4=51-75 \%, 5=76-99 \%, 6=100 \%$. Sapling survival was significantly $(\mathrm{p}=0.02)$ higher on plots burned in the fall $(54 \%)$ than for those in plots burned in the spring (20\%).

At the end of the first growing season, seedling density did not differ between control and burn plots for the fall burn $(\mathrm{p}=0.46)$, but seedling density was higher on control plots than burn plots for the spring burn $(\mathrm{p}=0.05)$ (Fig. 2). Similarly, sapling density did not differ between control and burn plots for the fall burn $(\mathrm{p}=0.80)$, but was higher for the control burn ( $p=0.02$ (Fig. 3). Sapling growth rates during the year following the burn treatments did not significantly differ $(p=0.38)$ for the fall burn plots and were similar for burn and control plots in the spring, although there were not enough observations for a statistical test (Fig. 4). Crown mortality index tended to be lower for taller saplings, particularly in the fall (Table 1). Similarly, crown mortality index tended to be lower for saplings with a larger root collar diameter (Table 2).

\section{Seedlings per plot}

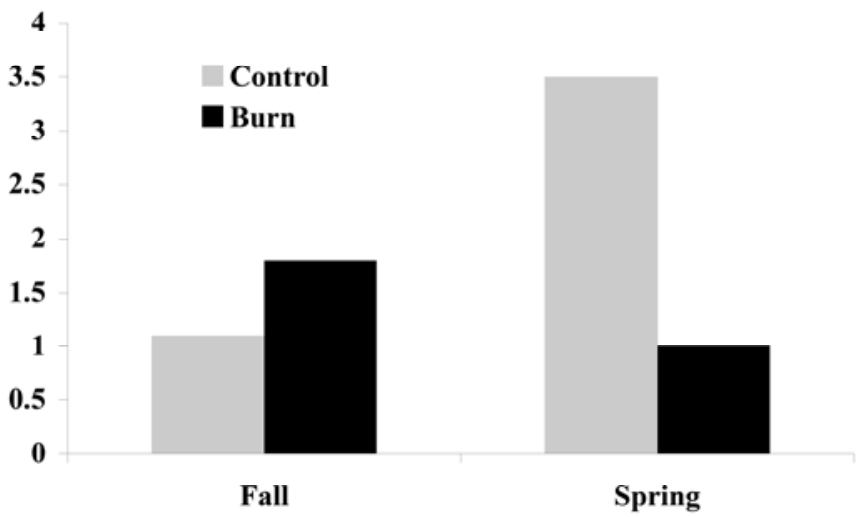

Fig. (2). Number of white pine seedlings (new germinants without woody stem) in plots burned in fall or spring compared to paired unburned control plots. Seedling density did not differ between control and burn plots for the fall burn $(\mathrm{p}=0.46)$, but seedling density was higher on control plots than burn plots for the spring burn $(\mathrm{p}=0.05)$.

\section{Saplings per plot}

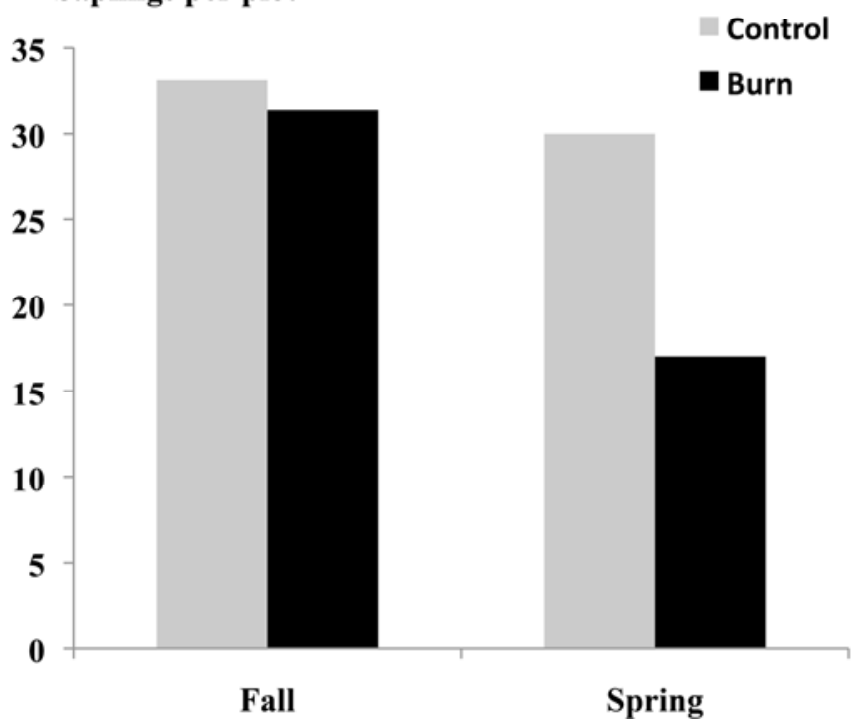

Fig. (3). Number of white pine saplings (past the new germinant stage but $<3 \mathrm{~m}$ tall) in plots burned in fall or spring compared to paired unburned control plots. Sapling density did not differ between control and burn plots for the fall burn $(p=0.80)$, but was higher for the control burn $(\mathrm{p}=0.02)$.

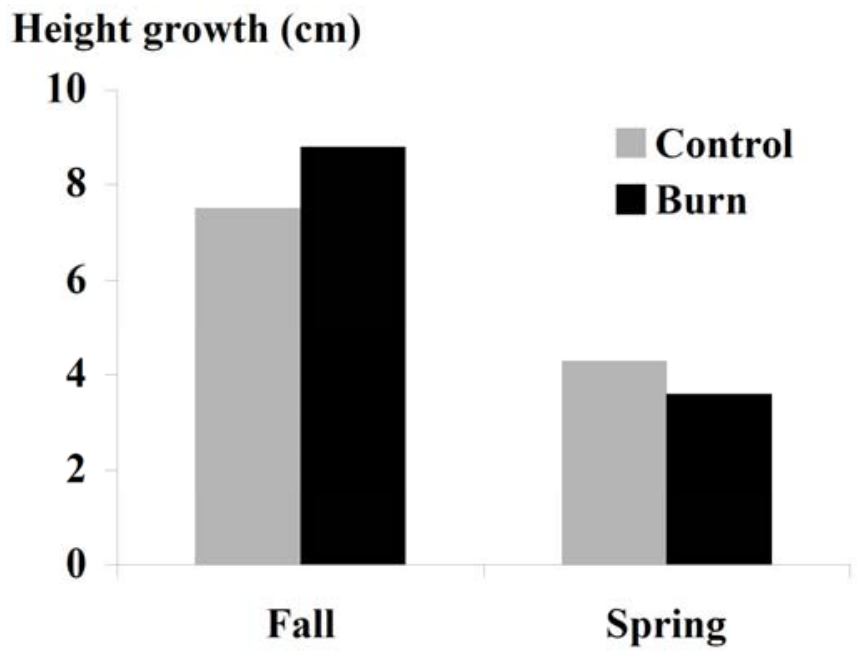

Fig. (4). Height growth of white pine saplings one growing season following prescribed burn treatments. Some of the burn plots did not have saplings to measure due to mortality. For fall burn plots $n=9$ and spring burn plots $n=3$. Sample size for control plots was $n$ $=10$ and $n=8$ for fall and spring plots, respectively. Sapling growth rates during the year following the burn treatments did not significantly differ $(\mathrm{p}=0.38)$ for the fall burn plots and were similar for burn and control plots in the spring, although there were not enough observations for a statistical test.

\section{DISCUSSION}

White pine regeneration was negatively affected to some extent by prescribed burning, particularly in the spring. We observed that newly-germinated seedlings were consumed by the fire regardless of season of burn. In addition, the removal of litter by fire did not allow for compensatory seedling recruitment in burned plots. Other studies have noted increased regeneration of this small-seeded species 
Table 1. Number of Saplings by Crown Mortality Index and Sapling Height Class Following Burning in Fall and Spring. Index Key: $1=0 \%$ of Crown Affected, $2=1$ $25 \%, 3=26-50 \%, 4=51-75 \%, 5=76-99 \%, 6=$ $100 \%$

Fall Burn

\begin{tabular}{|c|c|c|c|c|c|c|}
\hline Height Class (cm) & $\mathbf{1}$ & $\mathbf{2}$ & $\mathbf{3}$ & $\mathbf{4}$ & $\mathbf{5}$ & $\mathbf{6}$ \\
\hline \hline$<150$ & 0 & 0 & 2 & 3 & 4 & 5 \\
\hline $151-200$ & 0 & 3 & 5 & 3 & 4 & 2 \\
\hline$>250$ & 0 & 11 & 1 & 0 & 0 & 0 \\
\hline
\end{tabular}

Spring Burn

\begin{tabular}{|c|c|c|c|c|c|c|}
\hline Height Class (cm) & $\mathbf{1}$ & $\mathbf{2}$ & $\mathbf{3}$ & $\mathbf{4}$ & $\mathbf{5}$ & $\mathbf{6}$ \\
\hline \hline$<150$ & 0 & 0 & 0 & 0 & 2 & 11 \\
\hline $151-200$ & 0 & 2 & 0 & 1 & 5 & 9 \\
\hline$>250$ & 0 & 1 & 0 & 1 & 4 & 4 \\
\hline
\end{tabular}

Table 2. Number of Saplings by Crown Mortality Index and Sapling Root Collar Diameter Class Following Burning in Fall and Spring. Index Key: $1=0 \%$ of Crown Affected, $2=1-25 \%, 3=26-50 \%, 4=51$ $75 \%, 5=76-99 \%, 6=100 \%$

Fall Burn

\begin{tabular}{|c|c|c|c|c|c|c|}
\hline Root Collar Diameter (cm) & $\mathbf{1}$ & $\mathbf{2}$ & $\mathbf{3}$ & $\mathbf{4}$ & $\mathbf{5}$ & $\mathbf{6}$ \\
\hline \hline$<2$ & 0 & 1 & 3 & 3 & 4 & 16 \\
\hline $2-3$ & 0 & 9 & 4 & 2 & 2 & 0 \\
\hline$>3$ & 0 & 4 & 1 & 1 & 0 & 0 \\
\hline
\end{tabular}

Spring Burn

\begin{tabular}{|c|c|c|c|c|c|c|}
\hline Root Collar Diameter (cm) & $\mathbf{1}$ & $\mathbf{2}$ & $\mathbf{3}$ & $\mathbf{4}$ & $\mathbf{5}$ & $\mathbf{6}$ \\
\hline \hline$<2$ & 0 & 0 & 0 & 0 & 3 & 15 \\
\hline $2-3$ & 0 & 3 & 0 & 2 & 6 & 8 \\
\hline$>3$ & 0 & 0 & 0 & 0 & 2 & 1 \\
\hline
\end{tabular}

following fire $[10,19,22,23]$. Seedling density did recover on fall plots to a level similar to control plots, but seedling density was much lower than control plots for the spring burn. Since seed rain for white pine in this area occurs in the late fall and winter months (October-February), timing was favorable for some seedling establishment on fall plots, but spring fires likely consumed both seedlings and seeds, perhaps resulting in the observed low seedling densities on the spring burn plots. White pine seedling densities are positively related to the density of seed rain in a given year [11] and masting cycles for this species are typically on intervals of 3-5 years [8]. While we did notice some cones on mature white pines in the forest containing the experimental plots, the year following the fire did not appear to be a strong masting year, which may have led to low recruitment on these plots. Because of litter fall in the following year after fire, the window of opportunity for seedling establishment on the burned plots has probably closed regardless of seed rain in the second year following the fire.

For saplings, prescribed burns resulted in a relatively high mortality rate (20\% and 54\%) after the first growing season for fall and spring burns, respectively. Even for those saplings surviving the fire, all experienced some degree of crown mortality. The white pine saplings in the plots of this study were mostly $<3 \mathrm{~m}$ and typically still maintained foliage on lower branch whorls close to the leaf litter and were thus prone to crown scorch. Burns tended to most negatively affect smaller seedlings with lower root collar diameters, particularly for fall burns.

It has been observed that even with extensive crown scorch, white pine saplings may be able to survive dormant season burns [18]. The thin bark of white pine saplings probably contributed to the high level of damage observed in this study. Buds may also have been affected by fire. Methven [24] observed that fire can inhibit bud development and cause bud mortality in white pine. Growth was not affected by fire in the growing season following treatments. All saplings lost some photosynthetic capacity from the fire, but perhaps release from competition and mobilization of nutrients from the burn compensated for this loss.

It is worth noting, however, that of the 18 white pine sapling regeneration patches burned in this study (within which the burn plots were established), 12 of them had at least one surviving sapling. Nine of these were fall burn plots and three were spring burn plots. Thus, while sapling regeneration density was reduced, it was not eliminated by fire. Conceivably, a very low intensity prescribed fire may act as a thinning treatment for white pine regeneration patches. Surviving saplings may also benefit from fire due to reduction in competition from shrubs $[10,18]$.

Burning in the spring had a greater effect on crown mortality and sapling survival than burning in the fall. In the study area, the spring fire season is typically more severe, but burning conditions can be highly variable from day to day. We observed more intense and complete burns in the spring burn plots which likely resulted in the more severe effects of spring burns on white pine regeneration observed in this study. Spring burns may also have a greater negative effect on saplings because they are beginning to emerge from winter dormancy.

\section{CONCLUSIONS}

There is a growing awareness of the beneficial effects of prescribed fire in the management of forests. If prescribed burning is adopted on a wide scale in the southern Appalachians, it will be important to understand how it will affect existing advance regeneration. White pine is one of the few commercial tree species in our study area that has abundant advance regeneration in both the seedling and sapling size classes $[12,25]$. In this study, prescribed fire removed all seedling regeneration and affected, to some extent, all saplings, with particularly severe effects in the 
spring. Taller saplings with larger root collar diameters were the least affected. Burning in the fall appeared to allow for the recovery of seedling regeneration due to the timing of seed dispersal in late fall and early winter. Low intensity burns conducted in the mid to late fall may be the best time for minimizing damage to white pine advance regeneration.

\section{CONFLICT OF INTEREST}

The authors confirm that this article content has no conflict of interest.

\section{ACKNOWLEDGEMENTS}

We thank Ferrum College for providing field sites for this project. We also thank Rebecca Harbeck and Cecil Carter for help with data collection.

\section{REFERENCES}

[1] Delcourt PA, Delcourt HR. Long-term forest dynamics of the temperate zone. Ecol Stud 1987; 63: 439.

[2] Van Lear DH, Waldrop TA. History, uses, and effects of fire in the Appalachians. US: USDA For Serv Gen Tech Rep SE-54. vol, 20, 1989.

[3] McEwan RW, Long R, Hutchinson TF, et al. Temporal and spatial patterns of fire occurrence during the establishment of mixed-oak forests in eastern North America. J Veg Sci 2007; 18: 655-64.

[4] Nowacki GJ, Abrams MD. The demise of fire and "mesophication" of forests in the eastern United States. BioScience 2008; 58: 12338 .

[5] Abrams MD. Fire and the development of oak forests. BioScience 1992; 42: 346-53.

[6] McShea WJ, Healy WM, Devers P, et al. Forestry matters: decline of oaks will impact wildlife in hardwood forests. J Wild Manage 2007; 71: 1717-28.

[7] Ellison AM, Bank MS, Clinton BD, et al. Loss of foundation species: consequences for the structure and dynamics of forested ecosystems. Front Ecol Environ 2005; 9: 479-86.

[8] Wendel GW, Smith HC. Silvics of North America conifers. Washington D.C.: U.S. Forest Service, Agri Handbook 1990; vol. 1: p. 654 .
[9] Marshall P. The problem of eastern white pine (Pinus strobus L.) in southern New England: ecophysiology, site restriction, and historical land-use change. J Sustain For 2009; 28: 108-31.

[10] Weyenberg SA, Frelich LE, Reich PB. Logging versus fire: how does disturbance type influence the abundance of Pinus strobus regeneration? Silva Fenn 2004; 38: 179-94.

[11] Dovciak M, Reich P, Frelich L. Seed rain. Safe sites, competing vegetation, and soil resources spatially structure white pine regeneration and recruitment. Can J For Res 2003; 33: 1892-904.

[12] Fredericksen TS, Agramont AE. Regeneration patterns of eastern white pine (Pinus strobus L) in hardwood-dominated forests in Virginia, USA. New For 2013; 44: 51-61.

[13] Johnson EA. Fire and vegetation dynamics: studies from the North American boreal forest. Cambridge University Press 1992.

[14] Hibbs DE. White pine in the transition hardwood forest. Can J Bot 1982; 60: 2046-53.

[15] Beverly JL, Martell DL. Modeling Pinus strobus mortality following prescribed fire in Quetico Provincial Park, northwestern Ontario. Can J For Res 2003; 33: 740-51.

[16] Cook JE, Jensen N, Galbraith B. Compositional, cover, and diversity changes after prescribed fire in a mature eastern white pine forest. Botany 2008; 86: 1427-39.

[17] Beverly JL, Martell DL. Modeling prescribed surface-fire regimes for Pinus strobus conservation. Conserv Biol 2004; 18: 1541-52.

[18] McRae DJ, Lynham TJ, Frech RJ. Understory prescribed burning in red pine and white pine. For Chron 1994; 70: 395-401.

[19] Blankenship BA, Arthur MA. Prescribed fire affects eastern white pine recruitment and survival on eastern Kentucky ridgetops. South J Appl For 1999; 23: 144-50.

[20] Johnson EA, Miyanishi K. The need for consideration of fire behavior and effects in prescribed burning. Restor Ecol 1995; 3: 271-8.

[21] Ostry ME, Laflamme G, Katovich SA. Silvicultural approaches for management of eastern white pine to minimize impacts of damaging agents. For Pathol 2010; 40: 332-46.

[22] Whitney GG. Relation of Michigan's presettlement pine forests to substrate and disturbance history. Ecology 1986; 67: 1548-59.

[23] Burgess D, Robinson C, Wetzel S. Eastern white pine response to release 30 years after partial harvesting in pine mixedwood forests. For Ecol Manage 2005; 209: 117-29.

[24] Methven IR. Prescribed fire, crown scorch and mortality: field and laboratory studies and red and white pine. Canada: Can For Serv Petawawa For Exp Stn Inf Rep. PS-X-31, 1971.

[25] Carter WK, Fredericksen TS. Tree seedling and sapling density and deer browsing incidence on recently-logged and mature nonindustrial private forestlands in Virginia, USA. For Ecol Manag 2007; 242: 671-7. 